\title{
INCIDENCE OF CAMPYLOBACTER IN PIGS WITH AND WITHOUT DIARRHEA
}

\author{
José Rafael Modolo'; Luiz Florêncio Fernandes Margato ${ }^{1}$; Arnold Frederico Gottschalk ${ }^{1}$; \\ Carlos Alberto de Magalhães Lopes ${ }^{2 *}$
}

${ }^{1}$ Departamento de Higiene Veterinária e Saúde Pública, Faculdade de Medicina Veterinária e Zootecnia, Universidade Estadual Paulista, Botucatu, SP, Brasil. ${ }^{2}$ Departamento de Microbiologia e Imunologia, Instituto de Biociências, Universidade Estadual Paulista, Botucatu, SP, Brasil

Submitted: May 12, 1998; Returned to authors for corrections: September 24, 1998;

Approved: November 12, 1998

\section{SHORT COMMUNICATION}

\begin{abstract}
Two hundred pigs (1- 21 weeks old), from five piggeries in São Paulo State, Brazil, were divided in two groups of 100 animals each, G1 with diarrhea and G2 without diarrhea. Campylobacter was recovered from $43 \%$ of G1 and 34\% of G2 specimens, and was more frequently recovered from $0-4$ week old piglets. C. coli was the most common species ( $44.2 \%$ in $\mathrm{G} 1$ and $32.4 \%$ in G2), followed by $C$. jejuni/coli $(16.3 \%$ in $\mathrm{G} 1$ and $23.5 \%$ in G2). Campylobacter counts were significantly higher in $\mathrm{G} 1\left(\leq 10^{8} \mathrm{UFC} / \mathrm{g}\right)$ than in $\mathrm{G} 2\left(\leq 10^{4} \mathrm{UFC} / \mathrm{g}\right)(\mathrm{p}<0.01)$, which suggests that the bacterium may play a role at least in the aggravation of the diarrheic process.
\end{abstract}

Key words: Campylobacter, diarrhea, pigs

The primary habitat of some species of Campylobacter is the intestinal tract of warmblooded animals. Colitis attributed to $C$. jejuni has been reported in men, dogs, cats, ferrets and hamsters, though colonization by the organism usually causes mild diarrhea without severe colitis $(3,5,12)$. In pigs, the association of diarrhea with Campylobacter was first reported by Doyle $(6,7)$, who reproduced the so-called "pig dysentery" in healthy animals through experimental inoculation. Dysentery was also observed when Campylobacter coli was inoculated in gnotobiotic piglets by oral route. Sala et al. (16) observed diarrhea and bacterial dissemination in the lungs, kidneys and liver of pigs after experimental inoculation with thermophilic Campylobacter. There are many other reports on pig campylobacteriosis, such as Sala et al. (17), Boosinger and Powe (4), Smith et al.(22) and StichtGroh (23).

Since raw and undercooked animal products may be contaminated with microorganisms derived from the stools, representing a potential health hazard, and there is limited information as to whether the presence of Campylobacter in substantial numbers in feces can be linked with diarrhea in pig, this study was undertaken to investigate the incidence and number of the microorganism in feces of pigs with and without diarrhea.

\footnotetext{
* Corresponding author. Mailing address: Departamento de Microbiologia e Imunologia, Instituto de Biociências, UNESP, Caixa Postal 510, CEP 18618-000, Botucatu, São Paulo, SP, Brasil.
} 
Two hundred pigs (1-21 weeks old), from five piggeries in São Paulo State, Brazil, were divided into two groups, 100 animals each, G1 with diarrhea and $\mathrm{G} 2$ without diarrhea. Fecal samples from animals of G1 and G2 groups were collected in sterile flasks, shipped under refrigeration and stored at $\pm 20^{\circ} \mathrm{C}$ after the initial laboratory handling. For isolation of microorganisms, samples were directly smeared onto thioglycolate agar plates with $20 \%$ defibrinated bovine blood and Butzler selective supplement (SR 85-Oxoid) (TSA). Following this procedure, $1 \mathrm{~g}$ of feces was homogenized in $9 \mathrm{ml}$ of sterile saline $(0.85 \%)$. The homogenate was centrifuged at 2500 $\mathrm{rpm} / 5 \mathrm{~min}$ and the supernatant was filtered through an acetate membrane $(0.65 \mu \mathrm{M} \varnothing$ Millipore). Five drops of each filtrate were also streaked onto plates of TSA without Butzler selective supplement (TA). Plates of TSA and TA were incubated under microaerobic atmosphere for $72 \mathrm{~h}$ at $43^{\circ} \mathrm{C}$ and $37^{\circ} \mathrm{C}$, respectively. Colonies were examined for morphology and motility using phase contrast microscopy $(1000 \mathrm{x})$. The final identification was based on biochemical tests: catalase, hydrogen sulfide production with and without cysteine, oxidase, growth at $25^{\circ} \mathrm{C}$, at $43^{\circ} \mathrm{C}$, in $0.8 \%$ glycine and in $3.5 \%$ sodium chloride, reduction of sodium selenite, sodium hippurate hydrolysis and tolerance to 2, 3,5-triphenyl tetrazolium (TTC) $(8,9,11,18,20$, 21).

Enumeration of Campylobacter was done plating $0.1 \mathrm{ml}$ of each filtrate, submitted to serial dilutions in sterile saline, ranging from $10^{-1}$ to $10^{-10}$, onto TA plates, which were incubated under microaerobic atmosphere for $72 \mathrm{~h}$ at $43^{\circ} \mathrm{C}$. After incubation, plates showing 30-300 colony-forming units (CFU) were selected for counting.

The $\mathrm{X}^{2}$ test was used to compare G1 and G2 in relation to the incidence of Campylobacter according to age of the animals. Student's t test was used to evaluate the significance of the differences in the enumeration of Campylobacter in groups G1 and G2 (15).

The incidence and number of Campylobacter in fecal specimens of pigs with and without diarrhea are presented in Table 1. Campylobacter was recovered from $43 \%$ of $\mathrm{G} 1$ and from $34 \%$ of $\mathrm{G} 2$ specimens. These data are similar to those of Piazza and Lasta (14) and Smith et al. (22), but not to those of Kashiwazaki et al. (10). We found no statistically significant difference between the incidence of Campylobacter in $\mathrm{G} 1$ and $\mathrm{G} 2$, although the microorganism was more frequently recovered from the $0-4$ week old piglets. Despite the presence of Campylobacter in all age groups, it is difficult to consider that this microorganisms is the causative agent of diarrhea in $\mathrm{G} 1$, in view the broad spectrum of biological factors which affect the diarrheic process, including the association of various enteropathogenic agents. There was a significant difference $(p<0.01)$ between the density of Campylobacter in fecal specimens of $\mathrm{G} 1 \quad\left(\leq 10^{8}\right.$ $\mathrm{UFC} / \mathrm{g})$ and $\mathrm{G} 2\left(\leq 10^{4} \mathrm{UFC} / \mathrm{g}\right)$, which suggests that Campylobacter may at least play a role in the aggravation of the diarrheic process, possibly due to intestinal colonization.

Table 2 shows that there was a higher incidence of C. coli in G1 (44.2\%) than in G2 (32.4\%), though this species was the predominant in both groups. However, other thermophilic species were more frequently recovered from G2 than G1. C. jejuni biotype 2 showed a higher incidence than $C$. jejuni biotype 1 in both G1 and G2. With regards to Campylobacter lari (nalidixic acid resistant Campylobacter), in five out of 11 strains the phenotypic profile of sodium hippurate hydrolysis was comparable to that of $C$. jejuni, and in six the phenotype of TTC tolerance was comparable to that of C.coli. In this context, previous studies $(13,16)$ suggested that, based on the biochemical profile, $C$. lari may be considered a distinct species, and that C. lari, C. coli and C. jejuni present common phenotypic characteristics.

In this study, C. fetus subsp fetus was also isolated, which may have an epidemiological significance, in view the etiological correlation with enzootic abortion in sheep, sporadic abortion in bovines, diarrhea in calves and enteritis in dogs and cats $(1,2,19)$.

Table 1. Incidence of Campylobacter in fecal specimens of pigs with (G1) and without diarrhea (G2)

\begin{tabular}{|c|c|c|}
\hline Age (weeks) & $\begin{array}{c}\text { G1 } \\
\text { Positive Cultures (\%) } \\
\end{array}$ & $\begin{array}{c}\mathrm{G} 2 \\
\text { Positive Cultures (\%) } \\
\end{array}$ \\
\hline $0 \vdash 4$ & $23 / 47 \quad(48.9)$ & $10 / 24 \quad(41.7)$ \\
\hline $4+8$ & $15 / 42 \quad(35.7)$ & $14 / 41 \quad(34.2)$ \\
\hline $8+21$ & $5 / 11 \quad(45.5)$ & $10 / 35 \quad(28.6)$ \\
\hline Total & $43 / 100$ & $34 / 100$ \\
\hline
\end{tabular}

$\begin{array}{rrrr}0+4 \mathrm{x}^{2}=0.338 & 4+8 \mathrm{x}^{2}=0.022 & 8+21 \mathrm{x}^{2}=1.085 & \text { Total: } \mathrm{x}^{2}=1.710 \\ \mathrm{p}>0.50 & \mathrm{p}>0.50 & \mathrm{p}>0.30 & \mathrm{p}>0.10 \\ \mathrm{G} 1=\mathrm{G} 2 & \mathrm{G} 1=\mathrm{G} 2 & \mathrm{G} 1=\mathrm{G} 2 & \mathrm{G} 1=\mathrm{G} 2\end{array}$


Table 2. Species of Campylobacter isolated from fecal specimens of pigs with (G1) and without diarrhea (G2)

\begin{tabular}{lrrrr}
\hline Campylobacter & \multicolumn{2}{c}{$\mathrm{G} 1$} & \multicolumn{2}{c}{$\mathrm{G} 2$} \\
& $\mathrm{~N}^{\circ}$ & \multicolumn{1}{c}{$(\%)$} & \multicolumn{1}{c}{$\mathrm{N}^{\circ}$} & \multicolumn{1}{c}{$(\%)$} \\
\hline C. coli & 19 & $(44.2)$ & 11 & $(32.4)$ \\
C.jejuni biotype 1 & 3 & $(6.9)$ & 4 & $(11.8)$ \\
C.jejuni biotype 2 & 5 & $(11.6)$ & 5 & $(14.7)$ \\
C.jejuni /coli & 7 & $(16.3)$ & 8 & $(23.5)$ \\
C. lari & 6 & $(13.9)$ & 5 & $(14.7)$ \\
C. fetus subsp. fetus & 1 & $(2.4)$ & 0 & \\
Atypical strains & 2 & $(4.7)$ & 1 & $(2.9)$ \\
Total & 43 & $(100)$ & 34 & $(100)$ \\
\hline
\end{tabular}

\section{ACKNOWLEDGMENTS}

The authors are grateful to Tania Maria Martins and Adriana Cristina Pavan for excellent technical assistance and to Sonia Maria Faraldo for manuscript preparation.

\section{RESUMO}

\section{Incidência de Campylobacter em suínos com e sem diarréia}

Um total de 200 suínos (1 - 21 semanas de idade), originários de cinco criações localizadas no Estado de São Paulo, Brasil foi dividido em dois grupos de 100 animais caracterizando-se o grupo G1 de animais com diarréia e G2, sem diarréia. Campylobacter foi isolado em $43 \%$ das amostras provenientes de G1 e $34 \%$ de G2. O microrganismo foi mais frequentemente encontrado em leitões na faixa de 0 a 4 semanas de idade. Campylobacter coli foi a espécie mais comumente observada em G1 (44,2\%) e em G2 (32,4\%), seguido por Campylobacter jejuni/ coli com 16,3\% em G1 e 23,5\% em G2. As contagens de Campylobacter foram significativamente maiores $(\mathrm{p}<0,01)$ em G1 $\left(\leq 10^{8} \mathrm{UFC} / \mathrm{g}\right)$ do que em G2 $\left(\leq 10^{4}\right.$ $\mathrm{UFC} / \mathrm{g}$ ), fato que sugere que o microrganismo pode, pelo menos, atuar no agravamento do processo diarréico.

Palavras-chaves: Campylobacter, diarréia, suínos.

\section{REFERENCES}

1. Al-Mashat, R.R.; Taylor, D.J. Production of enteritis in calves by the oral inoculation of pure culture of Campylobacter fetus subsp. intestinalis. Vet. Rec., 112: 54-58, 1983.

2. Al-Mashat, R.R.; Taylor, D.J. Campylobacter spp in enteric lesions in cattle. Vet. Rec., 107: 31-34, 1980.

3. Altekruse, S.F.; Hunt, J.N.; Tollefson, L.K.; Madden, J.M. Food and animal sources of human Campylobacter jejuni infection. J. Amer. Vet.Med. Assoc., 204 (1): 57-61, 1994.

4. Boosinger, T.R.; Powe, T.A. Campylobacter jejuni infections in gnotobiotic pigs. Amer. J. Vet. Res., 49:456-458, 1988.

5. Butzler, J.P.; Dekeyser, P.; Detrain, M.; Dehaen, F. Related Vibrio in stools. J. Ped., 82: 493-495, 1973.

6. Doyle, L.P.A. Vibrio associated with pig dysentery. Amer. J. Vet. Res. 514: 3-5, 1944.

7. Doyle, L.P.A. The etiology of pig dysentery. Amer. J. Vet. Res., 9: 50-53, 1948

8. Harvey, S.M. Hippurate hydrolysis by Campylobacter fetus. J Clin. Microbiol., 11:435-437, 1980.

9. Harvey, S.M.; Greenwood, J.R. Relationship among catalase positive Campylobacter determined by deoxyribonucleic acid hybridization. Intern. J Syst. Bacteriol., 33: 275-284, 1983.

10. Kashiwazaki, M.; Namioka, S.; Satoh, Y. Isolation of Vibrio coli from pigs in Japan. Jpn J Vet Med Assoc, 23: 282-286, 1970.

11. Leaper, S.; Owen, R.J. Identification of catalase producing Campylobacter based on biochemical characteristics and cellular fatty acid composition. Curr. Microbiol., 6: 31-35 1981.

12. Manninger, K.I. Prescott, J.R ; Dohoo, I.R. Pathogenicity of Campylobacter jenuni from animal and humans. Infect. Immun., 38: 46-56, 1982.

13. Modolo, J.R.; Bisping, W.; Kirpal, G. Isolation of Campylobacter in calves with and without diarrhea. Pesq. Vet. Bras., 7:23-25, 1987.

14. Piazza, Z.; Lasta, J.A. Presence of zoonotic Campylobacter in cattle and pig for consumption in Argentina. Vet. Res. Comm., 10:303-308, 1986.

15. Pimentel Gomes, F. Curso de Estatística Experimental. 12 ${ }^{\mathrm{a}} \mathrm{ed}$. Piracicaba: Nobel, Piracicaba 1987, pp.207-298.

16. Sala, V.; Piccinini, R; Socci, A. Localization and characteristics of pig thermophilic Campylobacter in carriers of experimentally conditioned animals. Clin. Vet., 109: 236-242, 1986.

17. Sala, V.; Piccinini, R.; Socci, A. Osservazioni sulla coltivabilita di Campylobacter coli ed altri campylobactteri associati a patologia suina. Doc. Vet., Milano, 2-3: 111-112, 1987.

18. Skirrow, M.B.; Benjamin, J. 1001 Campylobacter: cultural characteristics of intestinal campylobacters from man and animals. J. Hyg., 85: 427-442, 1980.

19. Skirrow, M.B. Campylobacter enteritis in dogs and cats: a "new zoonosis". Vet. Res. Comm., 5:13-19, 1991.

20. Smibert, R.M. Family spirillaceae genus Campylobacter. Bergey's Manual of Systematic Bacteriology, $8^{\text {th }} \mathrm{ed}$. Baltimore Willians \& Wilkins., 1986, pp.207-219.

21. Smibert, R.M. The genus Campylobacter. Ann. Rev. Microbiol. 32: 673-709, 1978.

22. Smith, P.S.; Pinochet, L.; Alegria, G. Presencia de Campylobacter en cerdos lactantes com diarreia. Av. Cien. Vet., 1: 77-80, 1986.

23. Sticht-Groh, V. Campylobacter in healthy slaughtered pigs: a possible source of infections for man. Vet. Rec., 30: 104-106, 1982. 